Título do Trabalho

\title{
IMPACTOS AMBIENTAIS E SOCIAIS ACARRETADOS PELO MAU ARMAZENAMENTO DA MANIPUEIRA
}

Autora (s)

Letícia Florentino Dias de Oliveira; Aline Maria da Silva

Orientadora

Maria Betania Moreira Amador

Instituição de Ensino

Universidade de Pernambuco - Campus Garanhuns

E-mail(s)

letícia.Idias@bol.com.br, betaniaamador@yahoo.com.br

\section{Palavras-chave}

Sustentabilidade. Recursos naturais. Manipueira.

\section{INTRODUÇÃO}

A manipueira nada mais e do que uma calda que resulta da prensagem da mandioca quando do processo de obtenção de farinha. Trata-se de um líquido, antes subutilizado por ser venenoso e consequentemente, nocivo aos homens e animais, além de causador de impactos significativos ao meio ambiente. Por ser um resíduo que contem ácido cianídrico, muitos produtores despejam a manipueira de forma concentrada e em grande quantidade a céu aberto ou em cursos d'água agredindo assim, o meio ambiente com elevada carga de matérias orgânicas e ácido cianídrico. Esse procedimento sistematico está poluindo e, também desperdiçando um líquido que se percebeu ser precioso. 
Para que a manipueira deixe de ser um veneno e se transforme em um complemento alimentar seguro, basta submetê-la à fermentação anaeróbica, ou seja, deixar o líquido repousar durante 15 dias em um tanque cercado. O ácido cianídrico, considerado venenoso, evapora e resta a manipueira pronta para servir de complemento alimentar para o gado.

O produtor deve ter o cuidado de proteger o tanque, pois caso um animal venha beber o liquido durante a fermentação, pode ser fatal. A manipueira não é só um ótimo complemento alimentar para o gado, ela serve também para combater pragas e doenças, controlar formigas e insetos e até fabricar vinagre e sabão. (http://seuluiz.blogspot.com.br/2011/06/voce-conhecemanipueira.html)

Constitui-se ainda à fabricação de tijolos e a produção do bioetanol, misturada com óleo de mamona ela pode ser usada também no controle de carrapatos.

\section{OBJETIVO GERAL}

O presente trabalho objetiva mostrar, com base na literatura consultada e na experiência cotidiana, algumas possibilidades da dimensão sustentabilidade na exploração da mandioca, através do subproduto conhecido como manipueira. Assim, agricultores e proprietários de casas de farinha podem vir a obter uma renda extra, além de obter uma melhor orientação de como prevenir impactos no meio ambiente advindos da necessidade de armazenamento desse liquido, necessário para a evaporação do acido que, em excesso, contamina os cursos d'água.

\section{OBJETIVOS ESPECIFICOS}

- Prevenir a poluição de cursos d'água

- Prevenir a proliferação de insetos

- Orientar as doenças causadas pela manipueira

- Enfatizar os riscos do mau armazenamento da manipueira para sociedade 
- Incentivar para o melhor reaproveitamento desse líquido extraído da mandioca

\section{METODOLOGIA}

Os processos metodológicos utilizados para analise e caracterização da sustentabilidade em estudo, foram principalmente, entrevistas com algumas pessoas do município de Jupi, interior de Pernambuco, que de alguma forma estão envolvidas no processo da manipueira, pesquisas via internet, levantamento de dados com representações associativas existentes na cidade, além da tomada de fotografia.

\section{RESULTADOS}

O estudo sobre o liquido extraído da mandioca, resulta na conscientização da sociedade, para descarte correto do mesmo, e sobre os diversos fins que a manipueira possa vim a ter. Pois, esse descarte tomando a direção correta irá ajudar na economia de famílias que de diferentes formas lida com esse liquido amarelado e precioso e o mais importante, ajudar na preservação do meio ambiente.

\section{CONSIDERAÇÕES FINAIS}

Trabalhar a dimensão da Educação Ambiental para sociedades sustentáveis a partir das realidades locais, estabelecendo as devidas conexões com a realidade, objetivando a conscientização para a transformação. Incentivar a produção de conhecimento e praticas de Educação Ambiental. Estimulando posturas individuais e coletivas, bem como políticas institucionais que revisem permanentemente a coerência entre o que se diz e o que se faz, os valores de nossas culturas, tradições e historia. Fazer circular informações entre o saber e a memoria popular, e sobre iniciativas e tecnologias apropriadas ao uso de recursos naturais. 


\section{REFERÊNCIAS}

Você conhece a manipueira? Disponível em:

<http://seuluiz.blogspot.com.br/2011/06/voce-conhece-manipueira.html >. Acesso em: 10 de maio de 2013.

Manipueira, um líquido precioso. Disponível em:

$<$ http://www.embrapa.br/imprensa/noticias/2011/junho/2a-semana/manipueira-umliquido-precioso/\#>. Acesso em: 15 de maio de 2013.

Tijolo ecológico é feito com mistura de barro e manipueira. Disponível em: $<$ http://www.unisolbrasil.org.br/2012/02/14/tijolo-ecologico-e-feito-com-mistura-debarro-e-manipueira/>. Acesso em: 02 de junho de 2013.

Dr. Dráuzio: Gastrite. Disponível em: <http://drauziovarella.com.br/letras/g/gastrite/>. Acesso em: 02 de junho de 2013. 